\title{
Parasitic Worm in Tiger (Panthera tigris) at Serulingmas Zoological Garden Banjarnegara, Bandung Zoological Garden, and Indonesia Safari Park Bogor
}

\author{
(CACING PARASIT PADA HARIMAU (Panthera tigris) KEBUN BINATANG \\ SERULING MAS BANJAR NEGARA, KEBUN BINATANG BANDUNG, \\ DAN TAMAN SAFARI BOGOR) \\ Risa Tiuria ${ }^{1}$, Unita Pratiwi ${ }^{1}$, Ligaya ITA Tumbelaka ${ }^{2}$ \\ ${ }^{1}$ Laboratory of Helminthology; Division of Veterinary Parasitology \\ and Medical Entomology; Department of Animal Diseases \\ and Veterinary Public Health; \\ ${ }^{2}$ Division of Reproduction and Obstetric; Department of Veterinary Clinic, \\ Reproduction and Pathology; Faculty of Veterinary Medicine; Bogor \\ Agricultural University, jln Agathis, Kampus IPB Dramaga, \\ Bogor, Jawa Barat, Indonesia 16680 \\ Email: risatiprio@gmail.com
}

\begin{abstract}
ABSTRAK
Penelitian ini dilakukan untuk mengetahui jenis cacing parasitik pada harimau (Panthera tigris) di Taman Rekreasi Margasatwa Serulingmas (TRMS) Banjarnegara Jawa Tengah, Kebun Binatang Bandung (KBB), dan Taman Safari Indonesia (TSI) Bogor. Sebanyak 35 sampel tinja harimau dari tiga lembaga konservasi eks-situ, yaitu 4 ekor harimau Benggala dari TRMS, 12 ekor (4 ekor harimau Benggala dan 8 ekor harimau Sumatera) dari KBB, dan 19 ekor ( 4 ekor harimau Benggala dan 15 ekor harimau Sumatera) dari TSI Bogor. Semua sampel tinja diperiksa dengan metoda kualitatif (pengapungan dan sedimentasi) dan kuantitatif (metoda McMaster). Selain itu juga dilakukan pemupukan pada tinja yang positif telur strongylid. Cacing parasitik yang ditemukan dari penelitian ini adalah cacing ascarid (Toxocara sp, Toxascaris sp), cacing strongylid (Trichostrongylus sp, Ancylostoma sp, Cooperia sp), cacing oxyurid (Oxyuris sp) dan Strongyloides sp. Berdasarkan hasil penelitian, dapat disimpulkan bahwa prevalensi kecacingan pada harimau di TRMS 100\%, di KBB 50\%, dan di TSI Bogor 47,4\%. Cacing parasitik yang ditemukan pada harimau di TRMS adalah cacing ascarid (Toxocara sp), cacing strongylid (Ancylostoma sp, Trichostrongylus sp, Cooperia sp) and Strongyloides sp. Cacing parasitik yang terdapat pada harimau di KBB adalah cacing ascarid (Toxocara sp, Toxascaris sp), cacing strongylid (Ancylostoma sp, Trichostrongylus $\mathrm{sp}$ ), dan cacing oxyurid (Oxyuris sp). Cacing parasitik yang terdapat di TSI Bogor adalah cacing ascarid (Toxocara sp, Toxascaris sp), strongylid (Ancylostoma sp), dan cacing oxyurid (Oxyuris sp).
\end{abstract}

Kata-kata kunci: Panthera tigris; ascarid; strongylid; oxyurid; Strongyloides sp; prevalence index

\begin{abstract}
This research was done to infestigate the existence and the type of parasitic worms from feces of tiger (Panthera tigris) at Serulingmas Zoological Garden (TRMS) at Banjarnegara, Central Java, Bandung Zoological Garden (KBB), and Indonesia Safari Park Bogor (TSI). Total of 35 tigers feces samples were examined. They are taken from 4 Bengal tigers at Serulingmas Zoological Garden, 12 tigers (8 Bengal tigers and 4 Sumatran tigers) at Bandung Zoological Garden, and 19 tigers (4 Bengal tigers and 15 Sumatran tigers) at Indonesia Safari Park Bogor. All of the feces samples were examined with qualitative (flotation, and sedimentation) and quantitative (McMaster slide) method to know the existence of parasitic worm eggs. Moreover, a tiger feces that contain eggs of strongylid were cultured. Parasitic worms that were found in tigers from the research were ascarid (Toxocara sp, Toxascaris sp), strongylid (Trichostrongylus sp, Ancylostoma sp, Cooperia sp), ), oxyurid (Oxyuris sp) dan Strongyloides sp. The result showed that prevalence index of parasitic worms in tigers at TRMS, KBB and TSI were $100 \%, 50 \%$, and $47,4 \%$, respectively.
\end{abstract}


Parasitic worms at TRMS were ascarid (Toxocara sp), strongylid (Ancylostoma sp, Trichostrongylus sp, Cooperia $\mathrm{sp}$ ) and Strongyloides sp. Parasitic worms at KBB were ascarid (Toxocara $\mathrm{sp}$, Toxascaris $\mathrm{sp}$ ), strongylid (Ancylostoma sp, Trichostrongylus sp), dan oxyurid (Oxyuris sp). Parasitic worms at TSI were ascarid (Toxocara sp, Toxascaris sp), strongylid (Ancylostoma sp), oxyurid (Oxyuris sp).

Keywords: Panthera tigris; ascarid; strongylid; oxyurid; Strongyloides sp; prevalence index

\section{INTRODUCTION}

Tiger is among the animals in which its existence status based on Convention on International Trade in Endangered Species of Wild Fauna and Flora (CITES) is included in Appendix I and is classified as protected animals under the Law No. 5 of 1990 and Government Regulation No.7 of 1999. The decreased number of tigers is due to the reduction of natural habitats as the results of infrastructure development and the increasing number of illegal hunting. This is the reason why many conservation organizations, such as Serulingmas Zoological Garden (TRMS) at Banjarnegara, Central Java, Bandung Zoological Garden (KBB), and Indonesia Safari Park Bogor (TSI) conduct a tiger breeding efforts and treatment through programs of wildlife conservation and captive breeding of tigers in former ex-situ. As conservation organizations, one of the animal health problem that needs an attention is an infection of parasitic worms. This has to be done to prevent the animals in conservation institution from diseases and death and to achieve the goal of animal preservation.

Strongyloides parasitic worm infection was found in Panthera tigris altaica in Malaysia and wild carnivores in Japan (Fukase et al., 1985). Infection of parasitic worms of the genus Ancylostoma, Toxocara, and Toxascaris was also found in tigers in Thailand (Patton and Rabinowitz, 1994). Strongyloides sp, Ancylostoma sp, Toxocara sp, Toxascaris sp, Trichuris sp parasitic worm infections were found in Panthera tigris altaica in Far Eastern Rusia (Gonzalez et al., 2007). One way to diagnose the presence and type of parasitic worms in the animal's body is by examining the feces in order to find the parasitic worm eggs. By knowing the type of parasitic worm that infects the tiger, preventive measures and proper treatment can be done. This is an important action to keep conserving tigers from extinction. Whether or not good health management can reduce worm investation in the tiger can also be seen through this research.

This study aims were to determine the presence and type of parasitic worms in the tiger
(P. tigris) in the three ex-situ conservation parks on the island of Java, Serulingmas Zoological Garden Banjarnegara, Bandung Zoological Garden, and Indonesia Safari Park Bogor.

The results of this study may increase knowledge and initial information about the presence and type of parasitic worm that infects the tiger in the Serulingmas Zoological Garden at Banjarnegara, Central Java, Bandung Zoological Garden, and Indonesia Safari Park Bogor. The information obtained can be used as a basis for preventive action in order to reduce the possibility of parasitic worm infections in tigers. This research also notes the appropriate usage of anthelmintic to treat the infection on tiger caused by parasitic worm .

\section{RESEARCH METHODS}

The study was conducted in three ex-situ conservation institutions, i.e: Serulingmas Zoological Garden Banjarnegara, Bandung Zoological Garden, and Indonesia Safari Park Bogor. Sample examination was conducted at the Laboratory of Helminthology, Division of Veterinary Parasitology and Medical Entomology, Department of Animal Diseases and Veterinary Public Health, Faculty of Veterinary Medicine, Bogor Agricultural University.

Materials used for this research were feces of Bengal and Sumatran tigers, salt and sugar solution flotation, methylen blue, lugol, and vermiculite. The tools used for this were digital scales, tea strainer with holes sized 750-900 x 600-675 ìm, sieve-story, McMaster slide, Baermann glass or modification of it, a light microscope, a video micrometer, refrigerator, and digital cameras.

\section{Sampling}

Samples of feces were taken from each tiger in Serulingmas Zoological Garden Banjarnegara, Bandung Zoological Garden, and Indonesia Safari Park Bogor. Samples were taken from the feces of Sumatran tigers and Bengal tigers. The sample was obtained by taking the fresh feces directly or no more than two hours 
from animal defecation. Samples of feces were then stored in a temperature of $4^{\circ} \mathrm{C}$.

\section{Identification of Parasitic Worms}

All examinations of both eggs and larvae were done using microscope with objectmagnification of 10 and 40 times. Worm eggs and larvae found were measured and photographed with a video micrometer. Identification is based on morphology and morphometry worm eggs or larvae. Samples of feces obtained were examined through a qualitative approach, i.e: by flotation, and sedimentation examination (Gonzalez et al. 2007). In addition, samples of feces were also examined through a quantitative approach, which was done by counting the number of worm eggs per gram feces (EPG)/Mc Master method (Bhattacharya et al., 2012). The positive samples of feces contained strongylid type of eggs were then fertilized using vermiculite (Hansen and Perry, 1993).

\section{Data Analysis}

The data was analyzed descriptively based on results in the identification and calculation of parasitic worms eggs or larvae.

\section{RESULTS AND DISCUSSION}

The Diversity of Parasitic Worms in Tiger

A total of 35 tigers were examined from three ex-situ conservation park, i.e: four tigers in Serulingmas Zoological Garden Banjarnegara, 12 tigers in Bandung Zoological Garden, and 19 tigers in Indonesia Safari Park Bogor. Parasitic worms which were found from the identification of eggs and larvae were the worms from genus Toxocara, Toxascaris, Strongyloides, Ancylostoma, Trichostrongylus, Cooperia, and Oxyuris (Table 1). Toxocara and Ancylostoma were the parasitic worms found in the three research sites.

\section{Identification of Parasitic Worms}

Toxocara. Worm eggs in Figure 1 has special features, such as subglobular shape, transparent cells, pitted shell, a thick layer of albumin and sized from 59.2 to 75.0 ìm for length and 53, 2 to 68.2 ìm for the width. According to Patton and Rabinowitz (1994). the shape of eggs resulted from identification has a similar characteristics with the genus of Toxocara eggs. According to Bhattacharya et al.
(2012), eggs of T. mystax or T. cati has a diameter of 65-75 ìm.

Toxascaris. Other worm eggs were found in slightly ovoid shaped, smooth thick shell, light colored, and sized for 73.5 to 84.9 ìm long and 58.6 to 72.6 im for the width. Based on the observation on the shape, structure, and measurement of egg in Figure 2, it can be seen that the eggs were Toxascaris sp from Ascarididae family. According to Bhattacharya et al. (2012), T. leonina or T. Limbata eggs in cats has a length of 75-85 ìm and width of 60-75 ìm.

Strongyloides. Strongyloides eggs that were found were oval, thin-shelled and already embryonated into larvae (Fig. 3a). This egg had a length of 49.0 to $53.3 \mathrm{im}$ and width from 34.2 to $36.1 \mathrm{im}$. Strongyloides eggs sized 50-58 ìm to 30-34 ìm for length and width (Shrikhande et al., 2008) .

Larvae resulted from fertilization has special features, such as sheath absent, short and rounded esophagus, the tip of the tail appears to be "notched" and sized of 331.2 to 443.7 ìm (Fig. $3 \mathrm{~b})$. This kind of larvae is called rhabditiform larvae. Rhabditiform larvae is a first-stage larvae (L1), which lives freely and is not a parasitic, but it can also develop into parasitic filariform larvae. The larvae are believed to be the secondstage larvae that will develop into free form of male and female worm due to the optimum environmental conditions acccording to Mahmoud and Azazi (2014). The length of Strongyloides stercoralis first-stage larvae or form rhabditiform is between 180-380 ìm and

Table 1. Types of parasitic worms in the study site

\begin{tabular}{llccc}
\hline & & \multicolumn{3}{c}{ Research Sites } \\
\cline { 2 - 5 } No. Parasitic worms & TRMS & KBB & TSI \\
\hline 1. Toxocara sp & + & + & + \\
2. & Toxascaris $\mathrm{sp}$ & - & + & + \\
3. Strongyloides sp & + & - & - \\
4. Ancylostoma sp & + & + & + \\
5. & Trichostrongylus $\mathrm{sp}$ & + & + & - \\
6. & Cooperia $\mathrm{sp}$ & + & - & - \\
7. & Oxyuris $\mathrm{sp}$ & - & + & + \\
\hline
\end{tabular}

Description: (+): found in eggs or larvae of parasitic worms; (-): can not find eggs or larvae of parasitic worms; TRMS: Serulingmas Zoological Garden; KBB: Bandung Zoological Garden; TSI: Safari Park of Indonesia. 


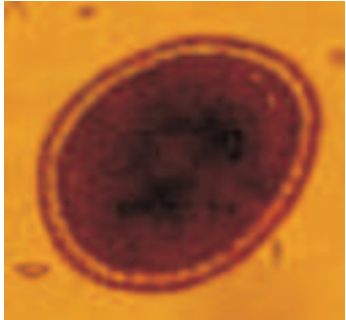

(a)

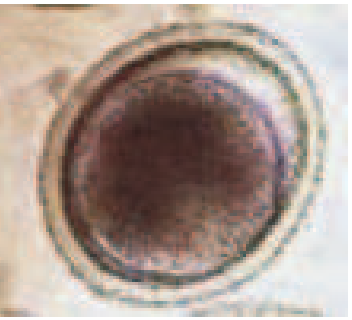

(b)

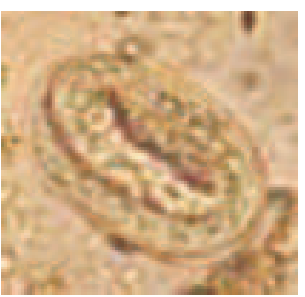

(a)

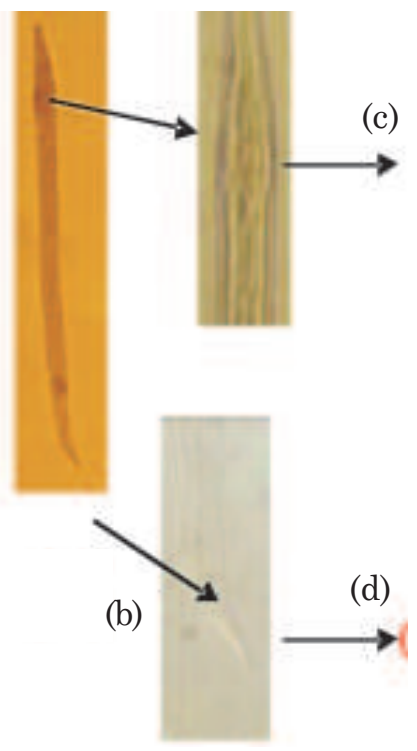

(d)

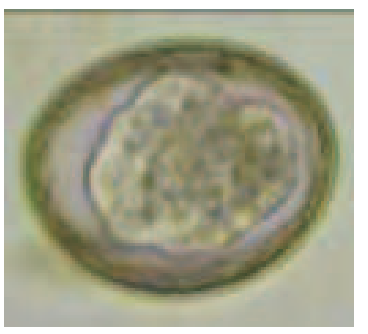

(a)

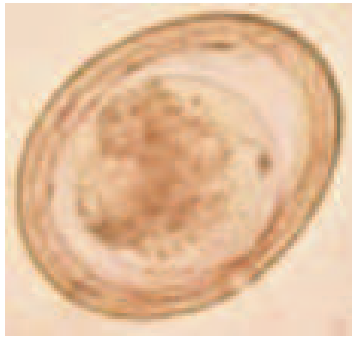

(b)

Figure 2.Toxascaris egg research (a) and worm egg Toxascaris leonina from the literature (CAPC 2009) (b).

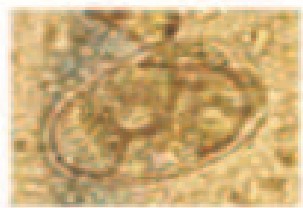

(a)
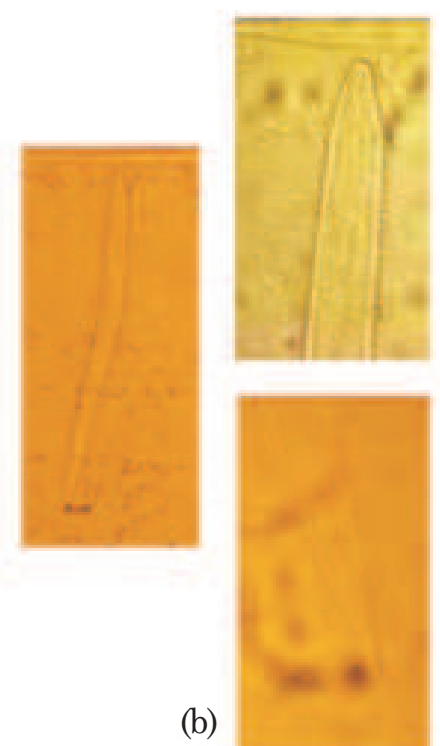

(b)

Figure 3.Strongyloides egg research (a); larvae Strongyloides form rhabditiform fertilization outcome (b); the rhabditiform esophagus (c); the tip of the tail appears to be "notched" (d).

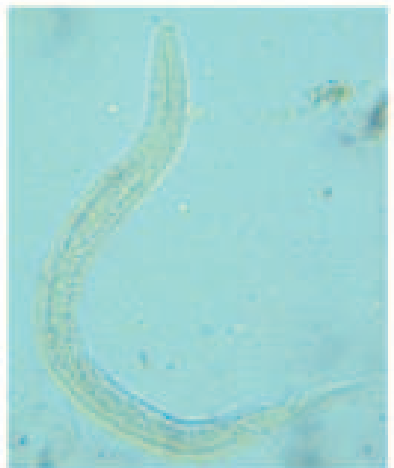

(c)

Figure 4.Ancylostoma egg research results (a); larvae of Ancylostoma result of fertilization (b); Ancylostoma larvae from the literature (CDC 2009) (c).

the length of third stage larvae or other forms of filariform is approximately 500-550 ìm.

Ancylostoma. Other parasitic worm eggs found were ovoid shaped, thin walled, transparent, containing 4-6 blastomeres, and had a length of 56.3 to 70.0 ìm and width from 30.8 to
40.8 ìm (Fig. 4a). According to Bante et al. (2013) , Ancylostoma eggs belong to the strongylid type, i.e. thin-walled, ovoid, and when they were removed from the body, they usually had 2-8 blastomeres. According to Bhattacharya et al. (2012), worm eggs $A$. caninum and $A$. 
tubaeforme have size of 56-75 ìm length and 34$47 \mathrm{imm}$ width.

Larvae obtained from the results of fertilization has a characteristic, such as sheath present, having buccal cavity, straight tail, and has a length of between 519.2 to 619.6 ìm (Fig. 4b). According to Bjork et.al. (2000), Ancylostoma larvae have a size between 500600 ìm (Fig. 4c).

\section{Strongyle Type of Eggs}

Observation of other types of eggs found the strongyle type of eggs. Strongyle eggs are those coming from the groups of superfamily of Trichostrongyloidea and Strongyloidea (Gonzalez et al., 2007). Strongyle eggs found in an ovoidshaped, thin-skinned, fully contained with inflated embryo and sized of 50 to $54.2 \mathrm{im}$ in length and from 28.1 to $33.1 \mathrm{im}$ width (Table 2).

First resulted larva from the fertilization of strongyle type of eggs sheath present, squareshaped head, straight esophagus, esophageal length less than 0,25 length of body, having refractile bodies, short tail shield, and the length from 610.6 to 813.8 ìm (Table 2). Based on identification, the larvae resulted from fertilization was Cooperia larva. According to Morgan et. al., (2004), larvae of Cooperia spp found in cattle have a length of about 666-866 ìm and according to (Gonzalez et al., 2007), the size can reach 956 ìm.

Other larvae resulting from the fertilization had a characteristic such as Cooperia larvae, which sheath present, straight esophagus, esophageal length was less than 0,25 length of body, short tailed shield, but these larvae did not have refractiled bodies and tapered or oval shape of head (Table 2). Based on the results of measurements, the length of larvae spanned from 598.9 to $754.3 \mathrm{im}$. According to Bjork et.al.,(2000), Trichostrongylus larvae have the same characteristics in Table 2 and length of 560-796 ìm.

\section{Oxyuris}

Other worm eggs found in feces examination of tiger were worm eggs from the family of Oxyuridae. Eggs of this worm had a very distinct characteristics: elliptical in shape, flatter on one side, thin-walled, transparent egg-wall, and somewhat thicker than the wall strongylid type of eggs (Fig. 5). The size was between 43.7 to 68.4 ìm for length and width from 25.2 to 38.6 ìm. According to Bhattacharya et al. (2012),
Oxyuris egg has a length 50-60 ìm and 20-32 ìm width.

\section{Distribution of Parasitic Worms}

A total of 35 samples of feces (4 samples from Serulingmas Zoological Garden Banjarnegara, 12 samples from Bandung Zoological Garden, and 19 samples from Indonesia Safari Park Bogor were taken. The result of the 35 feces samples were 19 samples (54.3\%) contained parasitic worm eggs and the remaining 16 samples (45.7\%) did not reveal any parasitic worm eggs. Based on the number of feces samples taken from each location, it can be noted that the prevalence of worm infection in tigers were 100\% for Serulingmas Zoological Garden Banjarnegara, $50 \%$ for the Bandung Zoological Garden, and $47.4 \%$ for the Indonesia Safari Park Bogor. The percentage spread of parasitic worms found in each location, was presented in Table 3 . Based on Table 3 it can be seen that in 19 of the positive samples, 13 samples (68.5\%) were Toxocara positive.

Genus Toxocara and Ancylostoma were found on all three study sites (Table 3). Thus we can conclude that the existence of a place or region does not affect the spread of worms of Toxocara and Ancylostoma.

In contrast with Toxocara and Ancylostoma, Oxyuris and Toxascaris were found only in KBB and TSI. Five samples of which one sample (5.3\%) from KBB and four samples (21.1\%) of TSI contained Toxascaris worm eggs. The remaining two samples (10.5\%) of KBB and one sample (5.3\%) of TSI were positively contained Oxyuris worm eggs. Distribution of eggs and larvae of Cooperia and Strongyloides worms were only found in feces samples from TRMS, whereas Trichostrongylus larvae were found in the feces of TRMS fertilization and KBB. The result of research showed that four types of parasitic worms that were found were zoonotic, that is parasitic worms of the genus Toxocara, Toxascaris, Ancylostoma, and Strongyloides. Toxocara, Toxascaris, and Strongyloides worms according to Mahmoud and Azazi (2014), and the Ancylostoma worm according to Otranto et al. (2015) is a parasitic worm that can also infect humans.

\section{Degree of Infection}

Based on the results of quantitative examination by counting the number of eggs per gram of feces (EPG) in every research park, the degree of EPG value could be calcuated for 


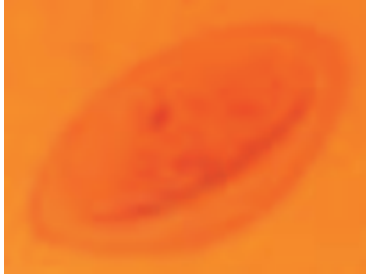

(a)

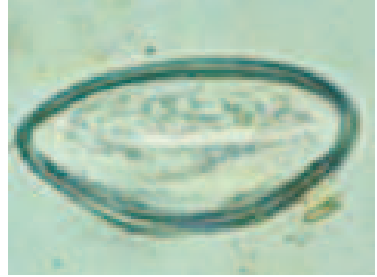

(b)
Figure 5.Oxyuris egg research results (a) and Oxyuris egg based on the literature (MacLean 2005) (b).
Bandung Zoological Garden (Table 4), Indonesia Safari Park Bogor (Tabe 5) and Serulingmas Zoological Garden Banjarnegara (Table 6). The absence of literature regarding the degree of infection in wildlife, especially tigers, makes it difficult for wildlife researchers to determine the severity of the parasitic worm investation. From the view of its physical condition, tigers at Bandung Zoological garden and Safari Park of Indonesia did not show any clinical symptoms, like emaciation, but the four tigers in Serulingmas Zoological Garden looked thin.

Table 2. Eggs, Cooperia larvae, and Trichostrongylus larvae results

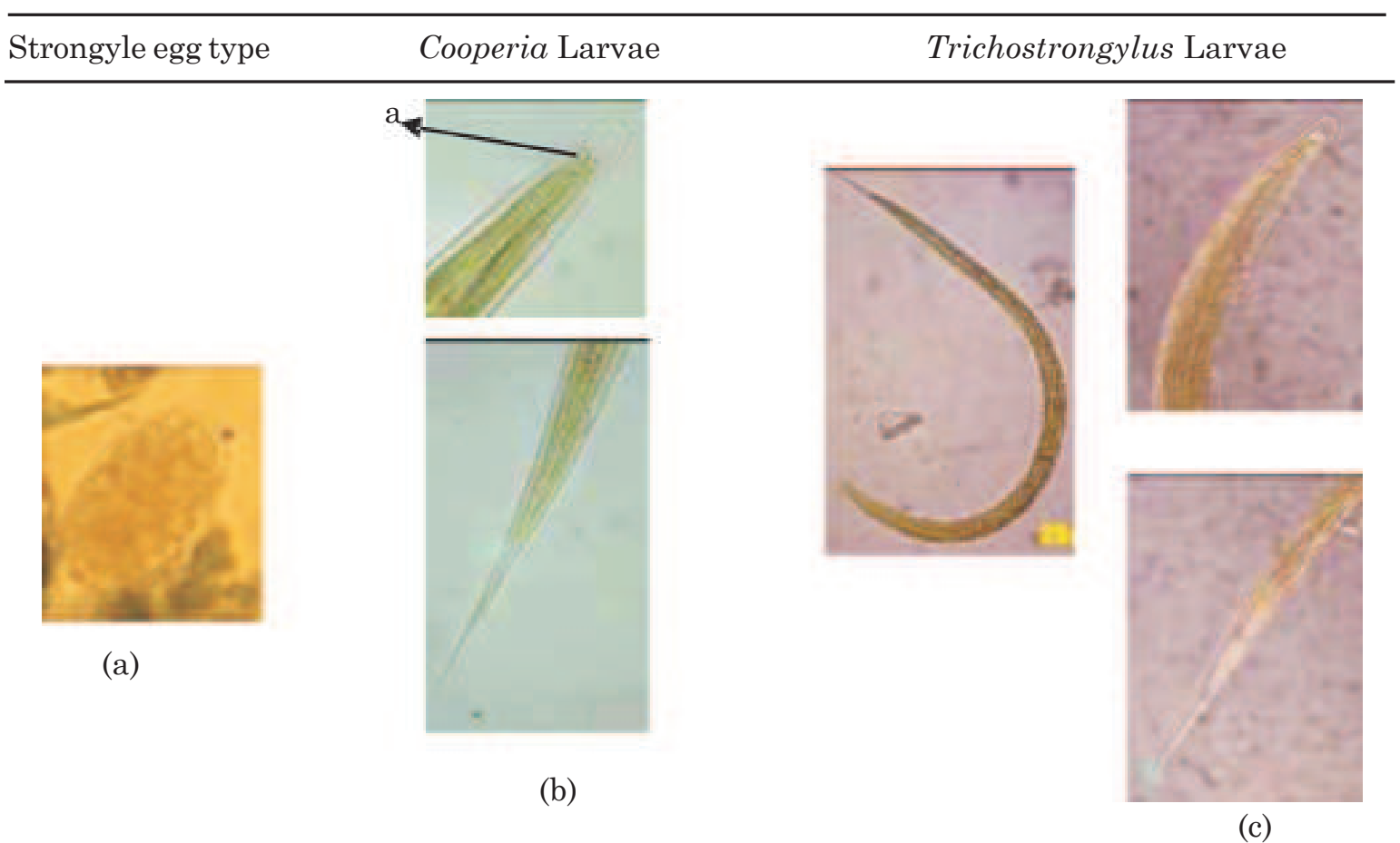

Description: a. refractile bodies

Table 3. Percentage spread of parasitic worms in the research location

\begin{tabular}{|c|c|c|c|c|c|}
\hline \multirow{2}{*}{ No. } & \multirow{2}{*}{ Parasitic worms } & \multicolumn{3}{|c|}{ Research Site } & \multirow{2}{*}{$\begin{array}{c}\text { Total } \\
\text { Percentage } \\
\text { (19 samples)(\%) }\end{array}$} \\
\hline & & TRMS (\%) & KBB (\%) & TSI (\%) & \\
\hline 1 & Toxocara sp & $21,1(4)$ & $21,1(4)$ & $26,3(5)$ & $68,5(13)$ \\
\hline 2 & Toxascaris $\mathrm{sp}$ & & $5,3(1)$ & $21,1(4)$ & $26,4(5)$ \\
\hline 3 & Ancylostoma sp & $15,8(3)$ & $5,3(1)$ & $5,3(1)$ & $26,4(5)$ \\
\hline 4 & Strongyloides sp & $5,3(1)$ & - & - & $5,3(1)$ \\
\hline 5 & Trichostrongylus $\mathrm{sp}$ & $5,3(1)$ & $5,3(1)$ & - & $10,6(2)$ \\
\hline 6 & Cooperia sp & $5,3(1)$ & - & - & $5,3(1)$ \\
\hline 7 & Oxyuris sp & - & $10,5(2)$ & $5,3(1)$ & $15,8(3)$ \\
\hline
\end{tabular}

Description: () represents the number of positive samples. 
Table 4. Results of tiger stool examination and the value EPG in Bandung Zoological Garden

\begin{tabular}{llcccccc}
\hline \multirow{2}{*}{$\begin{array}{l}\text { Animal Species/ } \\
\text { No. Location of The } \\
\text { Cage/Name/Sex }\end{array}$} & \multicolumn{6}{c}{ Parasitic Worm or Type of Egg } \\
\cline { 2 - 8 } & Toxocara & Toxascaris & Ancylostoma & Strongyloides & Tipe Strongyle & Oxyuris \\
\hline 1 & HS/KA/J & 66,7 & 333,3 & - & - & - & - \\
2 & HB/KA/B1 & - & - & - & - & - & - \\
3 & HB/KA/B2 & - & - & - & - & - & - \\
4 & HB/KA/B3 & - & - & - & - & - & 42600 \\
5 & HB/KA/J & 200 & - & - & - & - & - \\
6 & HS/KB/Wage/B & - & - & - & - & - & - \\
7 & HS/KB/Manik/B & - & - & - & - & - & - \\
8 & HS/KB/Fitra/B & - & - & - & - & - & - \\
9 & HS/KB/Marta/J & - & - & - & - & - & - \\
10 & HS/KB/Fitri/B & - & - & 200 & - & - & 3533,3 \\
11 & HS/KB/Oksa/J & $(+)$ & - & - & - & - & - \\
12 & HS/KB/Arjun/J & 133,3 & - & - & - & - & - \\
\hline
\end{tabular}

Table 5. Results of tiger stool examination and the value EPG in Safari Park of Indonesia

\begin{tabular}{|c|c|c|c|c|c|c|c|}
\hline \multirow{2}{*}{\multicolumn{2}{|c|}{$\begin{array}{l}\text { No. Animal Species/ } \\
\text { Name/ Sex }\end{array}$}} & \multicolumn{6}{|c|}{ Parasitic Worm or Type of Egg } \\
\hline & & Toxocara & Toxascaris & Ancylostoma & Strongyloides & Tipe Strongyle & Oxyuris \\
\hline 1 & HS/Jenaka/B & - & - & - & - & - & - \\
\hline 2 & HS/Cicis/B & - & - & - & - & - & - \\
\hline 3 & HS/Ara/B & - & - & - & - & - & - \\
\hline 4 & HS/Cut Nyak/B & - & - & - & - & - & - \\
\hline 5 & HS/Sutan/J & - & - & - & - & - & - \\
\hline 6 & HS/Ulu/J & - & - & - & - & - & - \\
\hline 7 & HS/Jabung/J & - & - & - & - & - & - \\
\hline 8 & HS/Imong/J & - & - & - & - & - & - \\
\hline 9 & HS/Tengku/J & - & - & - & - & - & - \\
\hline 10 & HS/Salamah/B & - & - & - & - & - & 2866,7 \\
\hline 11 & HS/Hilari/B & 133,3 & - & - & - & - & - \\
\hline 12 & HS/Minas/B & 66,7 & - & - & - & - & - \\
\hline 13 & HS/Siak/J & 200 & 133,3 & - & - & - & - \\
\hline 14 & HS/Gaga/J & - & 66,7 & - & - & - & - \\
\hline 15 & HS/Buyung/J & - & 400 & - & - & - & - \\
\hline 16 & HB Putih/Yui/B & - & - & - & - & - & - \\
\hline 17 & HB/Saskia/B & 700 & - & - & - & - & - \\
\hline 18 & HB/Denis/J & 200 & 700 & - & - & - & - \\
\hline 19 & HB/Salman/J & - & - & 66,7 & - & - & - \\
\hline
\end{tabular}

The Effects of Management Systems Towards the Prevalence of Worm

Infestation. Examination results showed that the Toxocara worm is the dominant worm found on a tiger (Table 7). The highest prevalence of Toxocara worm infection was found in TRMS Serulingmas, ie $100 \%$, meaning that all positive feces samples taken contained Toxocara. In addition, the highest prevalence of Ancylostoma worm investation was also found in the TRMS. Based on Table 7, it can also be seen that the highest diversity of parasitic worms were found in the TRMS and KBB which reached five genus. 
Table 6.Results of tigers stool examination and the value EPG in Serulingmas Zoological Garden

\begin{tabular}{|c|c|c|c|c|c|c|c|}
\hline \multirow{2}{*}{\multicolumn{2}{|c|}{$\begin{array}{l}\text { No. Animal Species/ } \\
\text { Name/ Sex }\end{array}$}} & \multicolumn{6}{|c|}{ Parasitic Worm or Type of Egg } \\
\hline & & Toxocara & Toxascaris & Ancylostoma & Strongyloides & Tipe Strongyle & Oxyuris \\
\hline 1 & HB/Edo/Male & 133,3 & - & 400 & 133,3 & - & - \\
\hline 2 & HB/Noni/Female & 600 & - & - & - & - & - \\
\hline 3 & $\mathrm{HB} / \mathrm{Aji} / \mathrm{Male}$ & 66,7 & - & $(+)$ & - & - & - \\
\hline 4 & HB/Zeto/Male & 133,3 & - & 733,3 & - & 200 & - \\
\hline
\end{tabular}

Description: HB: Bengal tiger; HS: Sumatran tiger; KA: cage above; KB: bottom cages; B: female; J: male; (): found in the flotation method

Table 7. Differences in the prevalence of parasitic worm each study site

\begin{tabular}{llccc}
\hline \multirow{2}{*}{ No. } & Parasitic Worm & \multicolumn{3}{c}{ Prevalence of Worm Investation (\%) } \\
\cline { 3 - 4 } & & TRMS & KBB & TSI \\
\hline 1 & Toxocara sp & 100 & 66,7 & 55,5 \\
2 & Toxascaris sp & - & 16,7 & 44,4 \\
3 & Ancylostoma sp & 75 & 16,7 & 11,1 \\
4 & Strongyloides sp & 25 & - & - \\
5 & Trichostrongylus sp & 25 & - & - \\
6 & Cooperia sp & 25 & 33,3 & 11,1 \\
7 & Oxyuris sp & - & & - \\
\hline
\end{tabular}

Table 8. Differences management systems that affect the prevalence of worm investation

\begin{tabular}{|c|c|c|c|}
\hline \multirow{2}{*}{$\begin{array}{l}\text { Management } \\
\text { System }\end{array}$} & \multicolumn{3}{|c|}{ Research Site } \\
\hline & TRMS Serulingmas & $\mathrm{KBB}$ & TSI \\
\hline $\begin{array}{l}\text { Feed Management } \\
\text { (Each individual) }\end{array}$ & $\begin{array}{l}\text { Monday-Saturday from } \\
3.5 \text { to } 4 \mathrm{~kg} \text { of chicken } \\
\text { meat \& Sunday from } \\
2.5 \text { to } 3 \mathrm{~kg} \text { of beef/goat/ } \\
\text { pork. }\end{array}$ & $\begin{array}{l}\text { Chicken } 8-10 \mathrm{~kg} / 2 \\
\text { days and interspersed } \\
1-2 \mathrm{~kg} \text { of beef. }\end{array}$ & $\begin{array}{l}\text { During the } 5 \text { days were } \\
\text { given } 4-5 \text { kg pork / } \\
\text { kangaroo. }\end{array}$ \\
\hline $\begin{array}{l}\text { Enclosure } \\
\text { Management }\end{array}$ & $\begin{array}{l}\text { Three heads are placed } \\
\text { in cages equipped with } \\
\text { a pool and enclosure } \\
\text { to show off to sleep } \\
1.5 \times 1,5 \mathrm{~m} 2 / \text { individu. } \\
\text { A tail in the cage } \\
2 \times 2 \mathrm{~m} 2 \text {. }\end{array}$ & $\begin{array}{l}\text { Cage show features } \\
\text { a pool at home to sleep } \\
\text { cage } 2 \times 3 \mathrm{~m} 2 \text { and } \\
\text { equipped with drinking } \\
\text { water bath and table. }\end{array}$ & $\begin{array}{l}\text { Cage to play } 6 \times 8 \mathrm{~m} 2 \\
\text { equipped with pool and } \\
\text { barn bed } 3 \times 4 \mathrm{~m} 2 \text {. }\end{array}$ \\
\hline $\begin{array}{l}\text { Maintenance } \\
\text { Management }\end{array}$ & $\begin{array}{l}\text { Feed given afternoon. } \\
\text { 1x/day cleaned cage } \\
\text { sleeping (morning). }\end{array}$ & $\begin{array}{l}\text { eed given afternoon. } \\
\text { 1x/day cleaned cage } \\
\text { sleeping (morning). }\end{array}$ & $\begin{array}{l}\text { Feed given afternoon. } \\
\text { Sleep cage is cleaned } \\
\text { every morning. The pool } \\
\text { is cleaned once a week. }\end{array}$ \\
\hline $\begin{array}{l}\text { Healthy } \\
\text { Management }\end{array}$ & $\begin{array}{l}\text { Treatment measures } \\
\text { (curatif). }\end{array}$ & $\begin{array}{l}\text { Preventive measures } \\
\text { (preventif) and } \\
\text { treatment. Preventif } \\
\text { actions include } \\
\text { granting anthelmintica } \\
\text { every } 3 \text { months and } \\
\text { giving multivitamins. }\end{array}$ & $\begin{array}{l}\text { Preventif action \& curatif. } \\
\text { Preventif actions include } \\
\text { monitoring reporting \& } \\
\text { keeper, giving anthel- } \\
\text { mintica every } 3 \text { months } \\
\text { and giving multivitamins. }\end{array}$ \\
\hline Prevalence & $100 \%$ & $50 \%$ & $47,4 \%$ \\
\hline
\end{tabular}


In each three different sites, there were different management systems conducted (Table 8). Based on research results, it can be seen in Table 8 that the difference of management system may affect the prevalence or incidence of worm investation. Table 8 showed that even the $\mathrm{KBB}$ and TSI has implemented a well management system, especially health management, the parasitic worm investation in the tigers were still found although in a low prevalence.

\section{Factors Affecting Worm Infection}

Worm infection that occurs in all three study sites can be caused by several factors, among others are various sources of infection, environmental conditions that support the occurrence of worms investation, and the vulnerability of the tiger itself. As conservation institutions, Serulingmas, KBB, and TSI places that are wide-opened, especially for cats and wild dogs which can be sources of worm infection on tiger. Cats and dogs that freely wander in the environment of Serulingmas Zoological Garden Banjarnegara, Bandung Zoological Garden, and Indonesia Safari Park Bogor may have been polluted the environment with their feces that contain eggs or larvae of parasitic worms. The tigers could be infected through food or drinking water which are contaminated with cat or dog feces. Poor environmental sanitation may also contribute to the occurrence of worm investation on the tiger such as cleaning the tigers cage without desinfectant as well as watery soil and poor drainage system surounding the cage (Morgan et al., 2004). Another important factor affecting the level of worm infection is the vulnerability of each individual tiger influenced by genetic factors, age and health condition of the tiger that could increase the risk to the worm investation due to the poor of immune status (McSorley et al., 2013).

Health management is important in preventing and reducing the parasitic worm infestation on the tiger. The study, which showed the prevalence of intestinal worms on tigers in Serulingmas $100 \%$, at KBB 50\%, and at the TSI $47.4 \%$ proves that the implementation of preventive measures from parasitic worm infestation is a very effective way to control or reduce the parasitic worm infestation. This showed that preventive measures (in Indonesia Safari Park Bogor and Bandung Zoological Garden) more effective than that of curative measures (Serulingmas Zoological Garden Banjarnegara). Feed management, housing, maintenance, and good health are also very important to the whole of management of captive tigers. These good implementation will improve animal health as well as resilience of the tiger from parasitic worm infection, and resulting the goal of the captive tiger conservation program can be achieved.

The research shows that, although the KBB and TSI has implemented good management of animal treatment and has conducted deworming program, parasitic worm infestation was still found on these two conservation institutions. This can be caused by several factors, among others, de-worming (anthelmintic given) factor is the most important ones. It is very important to regive anthelmintic by a certain period of time considering only $80 \%$ of it can eliminate the worms or larvae, but does not kill worm eggs. Repetition of giving anthelmintic can kill newly hatched larvae, so the larvae are halted develop into adult stage. In addition, granting the same anthelmintic continuously can cause resistency of parasitic worms to the drug. Another factor of why KBB and TSI were still infected by parasitic worms is the existence of infection sources such as infestated cats and dogs that live surounding the park and they can pollute the environment by their feces directly or through a water (Indonesia Safari Park Bogor is located in the rain area of Bogor), especially that of which the environmental sanitation is low.

\section{CONCLUSION}

Based on the research results, it can be concluded: The prevalence of worm investations on tigers are $100 \%$ at Serulingmas Zoological Garden Banjarnegara, 50\% at Bandung Zoological Garden, and $47.4 \%$ at Indonesia Safari Park Bogor. Parasitic worms found on the tiger at Serulingmas Zoological Garden Banjarnegara are Toxocara sp, Ancylostoma sp, Strongyloides sp, Trichostrongylus sp and Cooperia sp. Parasitic worms found on the tiger at Bandung Zoological Garden are Toxocara sp, Toxascaris sp, Ancylostoma sp, Trichostrongylus sp , and Oxyuris sp. Parasitic worms found on the tiger at Indonesia Safari Park Bogor are Toxocara sp, Toxascaris sp, Ancylostoma sp, and Oxyuris sp. 


\section{SUGGESTION}

Advice given to the manager of conservation organizations : the need for the implementation of feed management, housing, treatment, and good health in order to reduce the degree of parasitic worm infection and investation on the tiger. Additionally, precautionary act for instance deworming program should be conducted appropriately in order to reduce the possibility of parasitic worm infection and investation on the tiger. Anthelmintica should be given as a preventive measures program as well as to the tigers that have been positively infected with the eggs and larva of the parasitic worms.

\section{ACKNOWLEDGEMENT}

Authors thanks to Serulingmas Zoological Garden Banjarnegara, Bandung Zoological Garden and Indonesia Safari Park Bogor for the sampling permission, and also to Dr. Padmanaba for his correction and suggestion on the manuscript.

\section{REFERENCES}

Bante S, Bagherwal RK, Agrawal V. 2013. Prevalence of Helminth Parasites in Wild Animals of Zoological Park at Indore. Indian Vet $J$ 90(7): 84-86

Bhattacharya S, Dutta B, Mondal U, Mukherjee J, Mitra M. 2012. Helminthiasis in a Bengal Tiger (Panthera tigris tigris) . Anim Med Res (2): 184-188

Bjork KE, Averbeck GA, Stromberg BE. 2000. Parasites and parasite stages of Free Ranging Wild Lions (Panthera leo) of Northern Tanzania. Journal of Zoo and Wildlife Medicine 31(1): 56 - 61

Fukase T, Shiro C, Hiroshi I. 1985. Strongyloides planiceps (Nematoda; Strongyloididae) in Some Wild Carnivores. The Japanese Journal of Veterinary Science 47(4): 627-632

Giannelli A, Kirkova Z, Abtamo F, Latrofa M.S., Campbell B, Zizzo N, Cantacessi C. 2016.
Angiostrongylus chabaudi in felias : New Findings and a Review of the Literature. Veterinary Parasitology 228 : 188-192

Gonzalez P, E. Carbonell, V.Urlos, V.V. Rozhnov 2007. Coprology of Panthera tigris altaica and Felis bengalensis euptilurus from the Russian Far East. Journal of Parasitology 93(4) : $948-950$

Hansen J, Perry B. 1993. The Epidemology, Diagnosis, and Control of Helminth Parasites of Ruminants. Nairobi: The International Laboratory for Research on Animal Diseases.

Mahmoud MA and Azazi O. 2014. Prevalence of gastrointestinal parasites in captive zoo animals. Indian J Vet Med 35(1): 29-31

McSorley HJ, James PH, Rick MM. 2013. Immunomodulation by helminth parasites : Defining mechanisms and mediators. International Journal for Parasitology 43: 301-310

Morgan ER, Milner-Gulland EJ, Paul RT, Graham FM. 2004. Ruminating on complexity : macroparasites of wildlife and livestock. Trend in Ecology and Evolution 19(4): 181-188

Otranto D, Cantacessi C, Torres FD, Brianti E, Pfeffer M, Genchi C, Guberti V, Capelli G, Deplazes PT. 2015. The role of wild canids and felids in spreading parasites to dog's and cats in Europe. Part II : Helminth and Arthropods. Veterinary Parasitology 213: 24-37

Patton S, Rabinowitz AR. 1994. Parasites of Wild Felidae in Thailand: A Coprological Survey. Journal of Wildlife Diseases 30: 3.

Rickard LG, Foreyt WJ. 1992. Gastrointestinal parasites of Cougars (Felis concolor) in Washington and The First Report of Ollulanus tricuspis in A Sylvatic Felid from North America. Journal of Wildlife Disease. 28: 1 .

Shrikhande GB, Ashlesha KS, Suhasini SZ, Maske DK. 2008. Helminth parasites in Captive Wild Animals of Rajiv Gandhi Zoological Park. Veterinary World 1(7): 207 